\title{
GINSENG, GREEN TEA OR FIBRATE: valid options for nonalcoholic steatohepatitis prevention?
}

\author{
Mônica Souza de MIRANDA-HENRIQUES ${ }^{1}$, Margareth de Fátima Formiga de Melo DINIZ² \\ and Maria Salete Trigueiro de ARAÚJO3
}

\begin{abstract}
Objective - Panax ginseng, Camellia sinensis and bezafibrate were compared for their lipid-lowering, antioxidant and anti-inflammatory properties as potential agents to prevent nonalcoholic fatty liver disease and its progression to nonalcoholic steatohepatitis. Methods - Fifty Wistar rats were randomized into five groups: G1 (feed with standard diet); G2 (feed with high-fat diet with 58\% of energy from fat); G3 (high-fat diet + standardized Panax ginseng extract at $100 \mathrm{mg} / \mathrm{kg} / \mathrm{day}$ ); G4 (high-fat diet + standardized Camellia sinensis extract at $100 \mathrm{mg} / \mathrm{kg} /$ day); and G5 (high-fat diet + bezafibrate at $100 \mathrm{mg} / \mathrm{kg} /$ day), given by gavage. The animals were sacrificed eight weeks later and blood was collected for glucose, insulin, cholesterol, triglycerides, AST, ALT, alkaline phosphatase and gamma-glutamyl transferase determinations. The score system for nonalcoholic fatty liver disease was used to analyse the liver samples. Results and Conclusions - High-fat diet resulted in a significant increase in animal body weight, biochemical changes and enzymatic elevations. Steatosis, inflammation and hepatocellular ballooning scores were significant high in this group. The biochemical and histological variables were statistically similar in the bezafibrate group and control group. Treatment with Panax ginseng extract prevented obesity and histological features of nonalcoholic steatohepatitis (steatosis and inflammation) compared to high-fat diet. Camellia sinensis showed a less effective biochemical response, with small reduction in steatosis and inflammation but lower ballooning scores.
\end{abstract}

HEADINGS - Panax. Camellia sinensis. Liver diseases. Metabolic Syndrome X.

\section{INTRODUCTION}

Nonalcoholic fatty liver disease (NAFLD) has been described in clinical, experimental and epidemiological studies as hepatic manifestation of metabolic syndrome $^{(3,21)}$, which main components are abdominal obesity, atherogenic dyslipidemia, arterial hypertension, insulin resistance/glucose intolerance, proinflammatory and prothrombotic states ${ }^{(12)}$. Nowadays, NAFLD is considered the most common hepatic condition associated with increased aminotransferases and cryptogenic cirrhosis ${ }^{(6)}$ and that may progress to hepatocellular carcinoma ${ }^{(11)}$. Its prevalence has been estimated in $10 \%$ to $30 \%$ in Western countries ${ }^{(7)}$, and has been documented in $15 \%$ of individuals with normal weight and $80 \%$ obese $^{(27)}$. Other risk factors also play a role in the pathogenesis of NAFLD including gender, ethnicity, and genetic and immunological factors $^{(13)}$.

The pathophysiological mechanisms of NAFLD are not yet fully understood but accumulation of triglycerides in hepatocytes resulting from insulin resistance ${ }^{(29)}$ is the first step in the currently accepted pathogenetic model. Oxidative stress resulting from mitochondrial oxidation of fatty acids and expression of inflammatory cytokines have been implicated as secondary causal factors to liver damage, fibrosis and inflammation ${ }^{(8)}$. NAFLD is associated with a spectrum of morphological variations in disease progression with two distinct forms of presentation: hepatic steatosis (HS) characterized only by fat deposition in hepatocytes; and nonalcoholic steatohepatitis (NASH), a more severe form of disease with varying degrees of necrosis and inflammation ${ }^{(8)}$.

Still now, there is no licensed pharmacological treatment for NAFLD, a number of pharmacological agents have been investigated and tested, as antioxidant therapies and insulin-sensitising agents, however, the current treatment strategy for NAFLD is primarily focused on the control of risk factors including lifestyle changes, weight loss and regular exercise $^{(10,22,28)}$.

Departamento de Medicina Interna; ${ }^{2}$ Programa Produtos Naturais e Sintéticos Bioativos; ${ }^{3}$ Laboratório de Teste de Drogas. Universidade Federal da Paraíba, PB, Brasil. Correspondence: Mônica Souza de Miranda-Henriques. Centro de Ciências Médicas, Universidade Federal da Paraíba - Campus I. Jardim Universitário, s/n, CEP 58051900. Castelo Branco, João Pessoa, PB, Brasil. E-mail: mrsmonicca@gmail.com 
People are increasingly willing to use plant based medicinal drugs worldwide but the scientific literature lacks in evidence-based analysis of these compounds, making it difficult to establish its effectiveness. Experimental studies investigating the mechanisms of action of Panax ginseng and Camellia sinensis have been conducted in recent decades but most of them sought to assess qualitatively and quantitatively crude extracts and active principles alone ${ }^{(24)}$.

The current study was carried out to compare the effectiveness of Panax ginseng and Camellia sinensis in disease prevention using biochemical and histopathological parameters. Panax ginseng is known for its detergent and lipid-lowering properties through the action of ginsenosides, the main components of bioactive saponins ${ }^{(17)}$. It is thus expected to act on the first phase of the metabolic process characterized by increased intake of fatty acids to the liver. Since oxidative stress plays a central role in the development of steatohepatitis, Camellia sinensis was selected as a comparative natural product due to antioxidant effects of its catechins ${ }^{(26)}$. The positive control selected was a synthetic product, bezafibrate, wich is an agonist of peroxisome proliferator-activated receptors (PPAR) with lipid-lowering effects resulting from increased beta-oxidation of fat in the liver while reducing oxidative stress and directly preventing inflammation ${ }^{(27)}$.

\section{METHODS}

The study was approved by animal research Ethics Committee (number 0205/08) of Laboratory of Pharmaceutical Technology at Federal University of Paraíba. It followed the guidelines for the care and use of experimental animals according to Brazilian law $n^{\circ} 11.794$ (October, 8, 2008). Fifty Wistar rats aged 2 months weighing 200 to $250 \mathrm{mg}$, from the Thomas George Vivarium, were submitted to the experiment. The animals were kept in polyethylene cages (five animals per cage) under stable temperature and humidity conditions, free access to water and alternate 12-hour light-dark cycles, the amount of feed consumed by the animals was controlled at the end of each day. Animal weight was recorded the same day, once a week. The animals were divided into five groups: G1 (normal control group receiving standard diet); G2 (control group receiving high-fat diet with $58 \%$ of energy from fat, $18 \%$ from protein and $24 \%$ from carbohydrate); G3 (high-fat diet + standardized Panax ginseng extract at a dose of $100 \mathrm{mg} / \mathrm{kg} /$ day with $10 \%$ ginsenosides); G4 (highfat diet + Camellia sinensis extract at a dose of $100 \mathrm{mg} / \mathrm{kg} /$ day with $35 \%$ catechins and $15 \%$ epigallocatechin-3-gallate [EGCG]); and G5 (high-fat diet + bezafibrate at a dose of $100 \mathrm{mg} / \mathrm{kg} / \mathrm{day}$ ), the medication was given by gavage. The animals were sacrificed eight weeks later, after 8-hour fasting, by cervical dislocation under sedation. Blood was collected, centrifuged and blood glucose, insulin, total cholesterol, HDL cholesterol, VLDL cholesterol, triglycerides, serum aspartate aminotransferase (AST), alanine aminotransferase (ALT), alkaline phosphatase (ALP) and gamma-glutamyl transferase (GGT) were determined in a reference laboratory. The liver was removed and fixed in buffered formalin and prepared according to standard microtechniques ${ }^{(23)}$. Tissue sections $(5 \mathrm{~mm})$ were prepared, fixed and stained with hematoxylin-eosin, picrosirius red and Masson's trichrome and then examined using a histological scoring system, NAFLD activity score (NAS) ${ }^{(5,19)}$.

\section{Statistical analysis}

One-way and two-way analysis of variance (ANOVA), Tukey's multiple comparison tests, Dwass-Steel-ChritchlowFligner test and nonparametric Kruskal-Wallis test were used. All tests were analyzed at a 5\% significance level $(P<0.05)$. Stata v. 9.0, SPSS for Windows (Statistical Package for Social Sciences) v. 18.0, Statistical Data Analysis R - statistical computing and graphics, v. 2.13 .1 (2011-07-08) and MYSTAT - Statistical Analysis Product v. 12.0 were used in the analyses.

\section{RESULTS}

See Table 1, 2, 3 and Figure 1.

TABLE 1. Baseline and final weight $(\mathrm{g})$ in the experimental groups

\begin{tabular}{cccc}
\hline Groups & Baseline weight $(\mathrm{g})$ & Final weight $(\mathrm{g})$ & Average \\
G1 & $207 \pm 3.57$ & $335.4 \pm 11.83$ & $292.2 \pm 3.0$ \\
G2 & $241 \pm 3.5$ & $405.2 \pm 16.45$ & $346.4 \pm 7.32$ \\
G3 & $221.3 \pm 5.2$ & $350 \pm 6.3$ & $329.8 \pm 4.73$ \\
G4 & $228.5 \pm 5.42$ & $393.1 \pm 12.63$ & $324.5 \pm 6.81$ \\
G5 & $245.6 \pm 1.34$ & $354.6 \pm 13.74$ & $311.2 \pm 9.36$
\end{tabular}

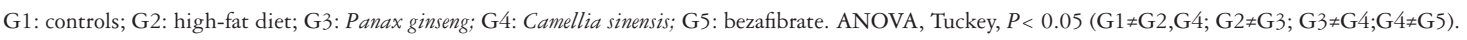


TABLE 2. Biochemical parameters described as average $\left({ }_{ \pm}\right.$Standard deviation) in the experimental groups

\begin{tabular}{|c|c|c|c|c|c|}
\hline Variables & \multicolumn{5}{|c|}{ Experimental groups $($ mean $\pm S D)$} \\
\hline Blood glucose & $95.6 \pm 28.7$ & $233.6 \pm 40.7$ & $131.1 \pm 44.6$ & $191.7 \pm 54.3$ & $155.0 \pm 27.5$ \\
\hline Insulin level & $1.68 \pm 0.07$ & $3.54 \pm 0.08$ & $1.74 \pm 0.05$ & $2.04 \pm 0.13$ & $1.98 \pm 0.11$ \\
\hline Cholesterol & $41.33 \pm 8.1$ & $53.20 \pm 6.2$ & $48.00 \pm 8.2$ & $48.33 \pm 15.6$ & $37.80 \pm 7.95$ \\
\hline VLDL & $7.1 \pm 21.6$ & $22.3 \pm 3.5$ & $14.8 \pm 4.3$ & $20.9 \pm 7.2$ & $9.8 \pm 2.3$ \\
\hline TGLs & $35.6 \pm 23.2$ & $111.6 \pm 18.9$ & $76.8 \pm 23.9$ & $103.8 \pm 36.5$ & $49.6 \pm 11.7$ \\
\hline ALP & $165.0 \pm 44.1$ & $180.1 \pm 58.6$ & $160.1 \pm 58.7$ & $158.7 \pm 92.3$ & $416.3 \pm 112.3$ \\
\hline AST & $49.1 \pm 17.6$ & $84.7 \pm 101.1$ & $68.78 \pm 10.45$ & $63.5 \pm 10.9$ & $45.6 \pm 9.6$ \\
\hline
\end{tabular}

G1: controls; G2: high-fat diet; G3: Panax ginseng; G4: Camellia sinensis; G5: bezafibrate. Results of Kruskal-Wallis H test of differences in biochemical parameters between the groups. To identify statistically significant differences mentioned above, between the groups of animals, convenient multi-Steel-Dwass Chritchlow-Fligner comparison test was carried out. Glucose

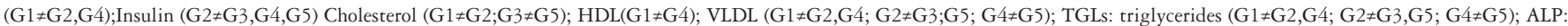
alkaline phosphatase $(\mathrm{G} 1 \neq \mathrm{G} 5 ; \mathrm{G} 2 \neq \mathrm{G} 5 ; \mathrm{G} 3 \neq \mathrm{G} 5 ; \mathrm{G} 4 \neq \mathrm{G} 5)$; AST: serum aspartate aminotransferase $(\mathrm{G} 1 \neq \mathrm{G} 2, \mathrm{G} 5 ; \mathrm{G} 3 \neq \mathrm{G} 5)$; ALT: alanine aminotransferase (G1 $\neq \mathrm{G} 2 ; \mathrm{G} 3 \neq \mathrm{G} 5)$; GGT: gamma-glutamyl transferase $(\mathrm{G} 1 \neq \mathrm{G} 5 ; \mathrm{G} 2 \neq \mathrm{G} 5 ; \mathrm{G} 3 \neq \mathrm{G} 5 ; \mathrm{G} 4 \neq \mathrm{G} 5) . P$ value $<0.05$

TABLE 3. Descriptive measures of histological features (steatosis, inflammation, and ballooning) between the groups at the end of the experiment

\begin{tabular}{|c|c|c|c|c|c|c|}
\hline & & Mean score & $\begin{array}{c}\text { Standard } \\
\text { deviation (SD) }\end{array}$ & $\begin{array}{c}\text { Standard error } \\
\text { (SE) }\end{array}$ & $\begin{array}{l}\text { Confidence } \\
\text { interval for the } \\
\text { mean }\end{array}$ & $\begin{array}{c}P \text {-value } \\
>0.05\end{array}$ \\
\hline \multirow{5}{*}{ Steatosis } & G1 & 0.00 & 0.00 & 0.00 & 0.00 & 0.00 \\
\hline & G2 & 3 & 0.42 & 0.13 & 2.50 & 3.10 \\
\hline & G3 & 1 & 0.99 & 0.31 & 0.19 & 1.61 \\
\hline & G4 & 2 & 0.42 & 0.13 & 1.90 & 2.50 \\
\hline & G5 & 0.00 & 0.00 & 0.00 & 0.00 & 0.00 \\
\hline \multirow{5}{*}{ Inflammation } & G1 & 0.00 & 0.00 & 0.00 & 0.00 & 0.00 \\
\hline & G2 & 1 & 0.48 & 0.15 & 0.95 & 1.65 \\
\hline & G3 & 1 & 0.92 & 0.29 & 0.14 & 1.46 \\
\hline & G4 & 1 & 0.63 & 0.20 & 1.35 & 2.25 \\
\hline & G5 & 0 & 0.52 & 0.16 & 0.03 & 0.77 \\
\hline \multirow{5}{*}{$\begin{array}{l}\text { Hepatocellular } \\
\text { ballooning }\end{array}$} & G1 & 0.00 & 0.00 & 0.00 & 0.00 & 0.00 \\
\hline & G2 & 2 & 0.42 & 0.13 & 0.90 & 1.50 \\
\hline & G3 & 1 & 0.00 & 0.00 & 1.00 & 1.00 \\
\hline & G4 & 1 & 0.00 & 0.00 & 0.00 & 0.00 \\
\hline & G5 & 1 & 0.42 & 0.13 & 0.10 & 0.50 \\
\hline \multirow{5}{*}{ NAS score } & G1 & 0 & 0.00 & 0.00 & 0.00 & 0.00 \\
\hline & G2 & 5 & 0.48 & 0.15 & 3.95 & 4.65 \\
\hline & G3 & 3 & 1.87 & 0.59 & 0.46 & 3.14 \\
\hline & G4 & 4 & 0.67 & 0.21 & 3.52 & 4.48 \\
\hline & G5 & 1 & 0.52 & 0.16 & 0.03 & 0.77 \\
\hline
\end{tabular}

G1: controls; G2: high-fat diet; G3: Panax ginseng; G4: Camellia sinensis; G5: bezafibrate.

(*) Statistically significant difference, ANOVA $(P<0.05)$. Diagnostic categorization: 0 to 2: not NASH; 3 to 4: probable, borderline NASH; 5 to 8: NASH. For the statistical differences

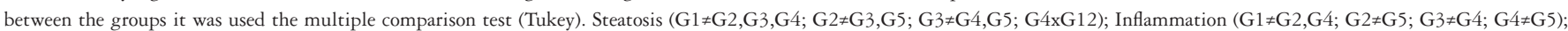
Hepatocellular ballooning $(\mathrm{G} 1 \neq \mathrm{G} 2, \mathrm{G} 3 ; \mathrm{G} 2 \neq \mathrm{G} 4, \mathrm{G} 5 ; \mathrm{G} 3 \neq \mathrm{G} 4, \mathrm{G} 5)$; NAS score $(\mathrm{G} 1 \neq \mathrm{G} 2, \mathrm{G} 3, \mathrm{G} 4 ; \mathrm{G} 2 \neq \mathrm{G} 1, \mathrm{G} 3 ; \mathrm{G} 3 \neq \mathrm{G} 1, \mathrm{G} 2, \mathrm{G} 3, \mathrm{G} 4 ; \mathrm{G} 4 \neq \mathrm{G} 1, \mathrm{G} 3, \mathrm{G} 5 ; \mathrm{G} 5 \neq \mathrm{G} 2, \mathrm{G} 4)$. 


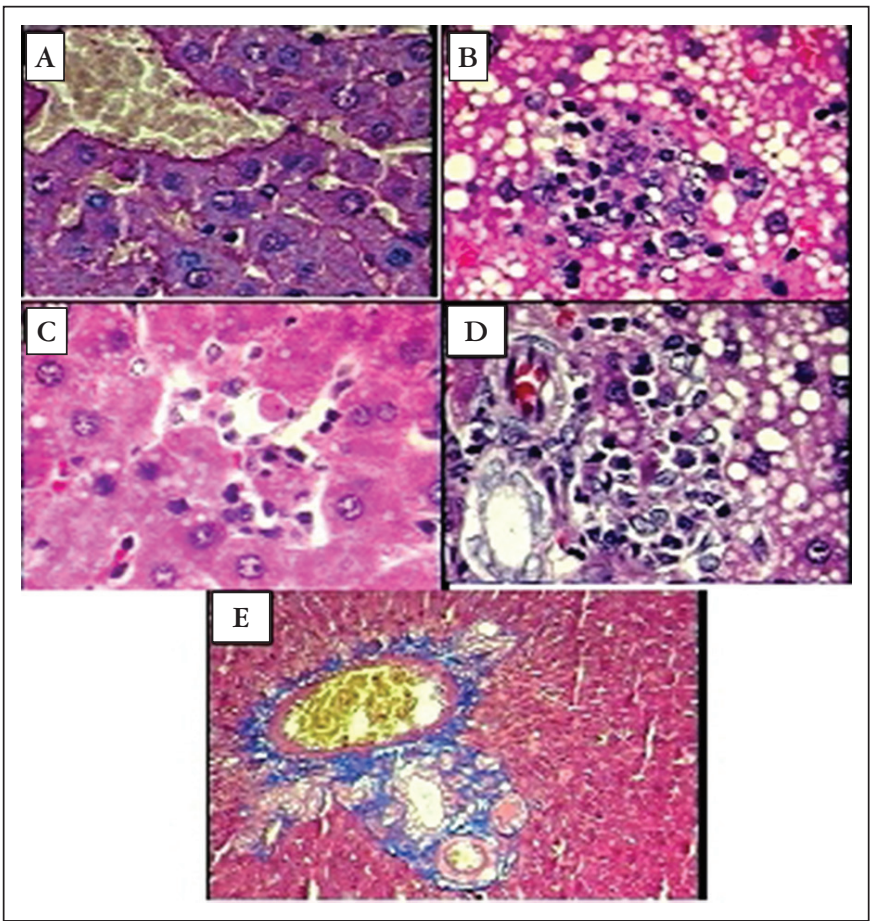

FIGURE 1. Liver: A) Control group - parenchyma with trabeculated isomorphic hepatocytes surrounding the terminal hepatic veins that have thin walls permeable to sinusoids. B) High-fat diet group - moderate to severe panacinar steatosis, inflammatory cell infiltrate of macrophages and granulocytes with lipogranuloma in zone 2. C) Panax ginseng group - mild microvesicular steatosis and rare hepatocellular ballooning. D) Camellia sinensis group - moderate to severe steatosis accompanied with inflammation. E) Portal space with vascular-biliary triad (artery, vein and bile duct) within matrix of loose collagen, without septum and no portal-parenchymal interface inflammation (A: picrosirius red, X400; C: hematoxylin and eosin, X100; B, D: hematoxylin and eosin, X400; E: Masson's trichrome, X100).

\section{DISCUSSION}

The study results are in agreement with previous studies that used the high-fat diet as an experimental model of obesity ${ }^{(31,33)}$. Wang et al. ${ }^{(32)}$ demonstrated that rats undergoing a 7 -week high-fat diet ( $58 \%$ of daily calories), high in saturated fat, had greater body fat than those fed on unsaturated fat or low-fat isocaloric diet.

A similar phenotype to the metabolic syndrome (obesity, hyperglycemia, hyperinsulinemia, hypercholesterolemia, hypertriglyceridemia, hyperuricemia, and low levels of HDL cholesterol) has been described in animals fed on a high-fat diet with $58 \%$ of energy from fat, $18 \%$ from protein and $24 \%$ from carbohydrate. In this experimental model of obesity, hepatocellular damage led to increased aminotransferase levels, particularly ALT, with no significant changes in cholestatic enzymes.

The present study animals receiving concomitant treatment with bezafibrate showed a percentage of weight gain similar to that seen in the standard diet group, demonstrating the effectiveness of this synthetic agent in controlling high-fat diet induced weight gain. The recognized agonist effect of bezafibrate on PPARs in the liver, adipose tissue and muscle results in improved control of glucose and lipid metabolism and fat storage as well ${ }^{(1)}$. Sasaki and colleagues ${ }^{(30)}$ also demonstrated the anti-obesity effect of bezafibrate through inhibition of fat accumulation in mice.

The Panax ginseng group showed similar results to the standard diet group, corroborating previous data on the effects of this herbal medicine on obesity management. Its effect has been associated with a probable agonist action on PPARg receptors ${ }^{(15)}$ and inhibition of both hyperinsulinemia and insulin resistance in adipose tissue. Since obesity is an inflammatory condition, Panax ginseng effect can be also explained by a proven anti-inflammatory action ${ }^{(20)}$. In addition to its agonist action on PPARg receptors, Panax ginseng has also been proved to regulate the lipoprotein lipase expression in adipose tissue, as well as to play a role in the regulation of glucose transporter 4 (GLUT4) and insulin receptor in skeletal muscle and liver ${ }^{(24)}$

In the current experiment, one group of rats received $\mathrm{Ca}$ mellia sinensis extract (100 mg/kg/day) with $35 \%$ of catechins. In the animals of the present study the group receiving green tea extract had a mean body weight lower than that of the high-fat diet group, but this difference was not statistically significant. Bose and colleagues ${ }^{(4)}$ also reported in an experiment under similar conditions a tendency to weight reduction as early as four weeks.

Treatment with bezafibrate prevented an increase in lipid and blood glucose levels with no increased aminotransferase levels, although higher levels of Alkaline phosphatase and GGT were found in this group. Treatment with Panax ginseng extract controled weight gain in animals with reduced levels of glucose and lipids. The use of Camellia sinensis extract did not either prevent weight gain or significantly reduced blood glucose, cholesterol, triglycerides. On the other hand, it was associated with increased levels of HDL cholesterol.

Although GGT increase has been reported ${ }^{(9)}$ as a sensitive diagnostic marker and predictor of NASH, this finding was not corroborated in high-fat diet group with hepatic necroinflammatory changes in the current study. GGT levels were significantly higher in the bezafibrate group.

Those animals treated with the synthetic product (bezafibrate) showed the best histological and biochemical responses when compared to other groups, with reduction of serum levels of total cholesterol, triglycerides, VLDL cholesterol, ALT and AST as well. It is of note that ALP and GGT levels were increased in the absence of histological signs of liver bile retention. Bertolami ${ }^{(2)}$ argued that bezafibrate may induce hepatocellular damage, which may cause increased aminotransferases, or cholestasis with increased bilirubins (especially direct bilirubin, ALP and GGT). Liver damage induced by lipid lowering agents is mainly hepatocellular, leading to increased AST and ALT. This is usually transient, asymptomatic and resolves with drug discontinuation.

In the present experiment, groups of animals fed on high-fat diet alone and those treated with Camellia sinensis showed sta- 
tistically significant higher rates of steatosis compared to other groups $(P<0.001)$. The extent of steatosis in the bezafibrate group was similar to that in the control group. The animals in the Panax ginseng group showed steatosis at an intermediate extent compared to other groups. The Camellia sinensis group also showed the highest percentages of inflammation, which were statistically similar to the high-fat diet group. No significant difference was seen between the bezafibrate and the control group, and between the Panax ginseng and Camellia sinensis groups compared to the high-fat diet group.

The highest percentage of hepatocellular ballooning was found in the high-fat diet group, with statistically higher values compared to other groups, followed by the Panax ginseng group. The greatest NAS scores were seen in the high-fat diet and Camellia sinensis groups with statistically significant differences compared to other groups. The bezafibrate group showed no statistically significant difference compared to the control group.

In this experimental context, these rats studied did not show any lobular, portal and periportal fibrogenic reactions. Yet, there has been reported that high-fat diet may prevent the development of histologic evidence of NASH, of which fibrosis is a major components ${ }^{(18)}$. Similarly, Nakamoto and colleagues $^{(26)}$, in a four week experimental study, failed to induce fibrosis associated with high-fat diet alone in rats.

The inflammatory activity associated with NAFLD was studied in the present study based on NAS score ${ }^{(19)}$. In a recent validation study ${ }^{(14)}$ found sensitivity and specificity over $80 \%$ for predicting steatohepatitis, and a score $\geq 4$ was the recommended cutoff for a NASH intervention program.

In this study, the high-fat diet group had higher NASH scores, histologically characterized by steatosis and moderate to severe inflammation, commonly accompanied by ballooning. Treatment with bezafibrate reversed NASH, with an almost overlapping of its morphological features in the liver with those seen in the control group. Ackerman and colleagues ${ }^{(1)}$ experimentally reported significant reduction of macrovesicular hepatic steatosis with bezafibrate but with no change in microvesicular lipid retention, inflammation, or fibrosis score. In mice with NASH, bezafibrate induced a marked reduction, and near elimination, of fat vesicles and improved NAS score ${ }^{(30)}$. Improvement of steatosis has been attributed to upregulation of PPAR- $\alpha$ receptors in mitochondrial fatty acid beta-oxidation, with increased catabolism of fatty acids and prevention of deposition of hepatocellular triglycerides ${ }^{(16,25)}$. The positive effects on PPAR $\gamma$ receptors are expressed predominantly in adipose tissue with involvement in the mechanisms of insulin resistance to upregulate GLU4. This receptor subtype promotes uptake of fatty acids to adipocytes, which induces their differentiation, increases triglyceride accumulation and reduces fatty acid influx to the liver ${ }^{(25)}$.

In this study, Panax ginseng induced partial NASH reversion with significant reduction in the final NAS score and histological hepatic features similar to those seen in the control group. Camellia sinensis showed a less effective biochemical response, with small reduction in steatosis and inflammation but lower ballooning scores.

\section{CONCLUSIONS}

The current study showed that drug-induced weight loss was associated with lower serum biochemical and histological hepatic changes, especially in the groups treated with bezafibrate and Panax ginseng. Bezafibrate also prevented histological damage, which was quite similar to that seen in the control group. The animals treated with Panax ginseng showed better biochemical response compared to those receiving of Camellia sinensis. Their biochemical profile was significantly similar to that seen in the control and bezafibrate groups. The biochemical parameters revealed that Panax ginseng was more effective in preventing increased level of blood glucose, cholesterol and VLDL cholesterol. It was also showed a reversal of histological liver damage, confirming other reports that Panax ginseng has hypoglycemic and lipidlowering properties. Nevertheless, randomized clinical studies are needed to investigate its use for prevention of NAFLD.

Miranda-Henriques MS, Diniz MFFM, Araújo MST. Ginseng, chá verde ou fibrato: opções válidas para prevenção da esteatohepatite não alcoólica? Arq Gastroenterol. 2014,51(3):255-60.

RESUMO - Objetivo - Panax ginseng, Camellia sinensis e bezafibrato foram comparados por suas propriedades hipolipemiantes, antioxidantes e anti-inflamatórias, como potenciais agentes capazes de prevenir a doença hepática gordurosa não alcoólica e sua progressão para esteato-hepatite não alcoólica. Métodos - Cinqüenta ratos Wistar foram distribuídos aleatoriamente em cinco grupos: G1 (alimentados com dieta padrão); G2 (alimentados com dieta hipercalórica com 58\% de energia a partir de gordura); G3 (dieta rica em gordura + extrato padronizado Panax ginseng em $100 \mathrm{mg} / \mathrm{kg} /$ dia); G4 (dieta rica em gordura + extrato de Camellia sinensis padronizado a $100 \mathrm{mg} / \mathrm{kg} / \mathrm{dia}$ ); e G5 (dieta rica em gordura + bezafibrato, a $100 \mathrm{mg}$ / kg / dia), administrado via oral. Os animais foram sacrificados após oito semanas e o sangue foi coletado para determinação da glicose, insulina, colesterol, triglicérides, AST, ALT, fosfatase alcalina e gama-glutamil transferase. O sistema NAS de pontuação para doença hepática gordurosa não alcoólica foi utilizado para analisar as amostras de fígado. Resultados e Conclusões - A dieta hipercalórica resultou em um aumento significativo no peso corporal dos animais, associado a alterações bioquímicas e elevações enzimáticas. Os escores de esteatose, inflamação e balonização hepatocelular foram significativamente mais elevados neste grupo. As variáveis bioquímicas e histológicas foram estatisticamente semelhantes entre os grupos bezafibrato e controle. O uso do extrato do Panax ginseng esteve associado a um menor ganho de peso dos animais, em média, bem como a menores índices nos escores de esteato-hepatite (esteatose e inflamação) em comparação com o grupo apenas alimentado com dieta hipercalórica. No grupo ao qual foi administrado o extrato da Camellia sinensis uma resposta bioquímica e histológica menos pronunciada foi observada, entretanto, com menores escores de balonização quando comparado ao grupos do Panax ginseng.

DESCRITORES - Panax. Camellia sinensis. Hepatopatias. Síndrome X Metabólica. 


\section{REFERENCES}

1. Ackerman Z, Oron-Herman M, Grozovski M, Rosenthal T, Pappo O, Link G, Sela BA. Fructose-induced fatty liver disease: hepatic effects of blood pressure and plasma triglyceride reduction. Hypertension. 2005;45:1012-8.

2. Bertolami MC. Mechanisms of hepatotoxicity. Arq Bras Cardiol. 2005;85:25-7.

3. Boppidi H, Daram SR. Nonalcoholic fatty liver disease: hepatic manifestation of obesity and the metabolic syndrome. Postgrad Med. 2008;120:1-7.

4. Bose M, Lambert JD, Ju J, Reuhl KR, Shapses SA, Yang CS. The major green tea polyphenol, -epigallocathechin-3-gallate, inhibits obesity, metabolic syndrome, and fatty liver disease in high-fat-mice. J Nutr. 2008;138:1677-83.

5. Brunt EM. Pathology of nonalcoholic fatty liver disease. Nature Reviews Gastroenterology and Hepatology. 2010;7:195-203.

6. Clark JM, Brancati FL, Diehl AM. The prevalence and etiology of elevated aminotransferase levels in the United States. Am J Gastroenterol. 2003;98:960-7.

7. Cobbold JF, Anstee QM, Taylor-Robinson SD. The importance of fatty liver disease in clinical practice. Proc Nutr Soc. 2010;69:518-27.

8. Day CP, James OF. Steatohepatitis: a tale of two hits? Gastroenterol. 1998;114:842-5.

9. Dixon JB, Bhathal PS, O'Brien PE. Weight loss and non-alcoholic fatty liver disease: falls in gamma-glutamyl transferase concentrations are associated with histologic improvement. Obes Surg. 2006;16:1278-86.

10. Duvnjak M, Tomasic V, Gomercic M, Smircic Duvnjak, L, Barsic N, Lerotic, I Therapy of nonalcoholic fatty liver disease: current status. J Physiol Pharmacol. 2009;60:57-66.

11. Farrell GC. The liver and the waistline: fifty years of growth. J Gastroenterol. Hepatol. 2009;24:105-18.

12. Grundy SM, Brewer HB, Cleeman JI, Smith SC, Lenfant C. Definition of Metabolic Syndrome: Report of the National Heart, Lung, and Blood Institute/ American Heart Association Conference on Scientific Issues related to Definition. Circulation. 2004;109:433-8.

13. Hijona E, Hijona L, Arenas JI, Bujanda L. Inflammatory mediators of hepatic steatosis. Mediators of Inflammation. 2010, Article 837419.

14. Hjelkrem M, Stauch C, Shaw J, Harrison SA. Validation of the non-alcoholic fatty liver disease activity score. Aliment Pharmacol Ther. 2011;34:214-8.

15. Hwang JT, Lee MS, Kim HJ, Sung MJ, HY Kim, Kim MS, Kwon DY. Antiobesity effect of ginsenoside Rg3 involves the AMPK and PPAR-gamma signal pathways. Phytother Res. 2009; 23: 262-6.

16. Kallwitz, ER, Mclachlan A, Cotler SJ. Role of peroxisome proliferators-activated receptors in the pathogenesis and treatment of nonalcoholic fatty liver disease. World J Gastroenterol. 2008;14:22-8.

17. Karu N, Reifen R, Kerem Z. Weight gain reduction in mice fed Panax ginseng saponin, a pancreatic lipase inhibitor. J Agric Food Chem. 2007;55:2824-8.

18. Koteish A, Diehl AM. Animal models of steatosis. Semin Liver Dis. 2001;21:89-104
19. Kleiner DE, Brunt EM, Van Natta M, Behling C, Contos MJ, Cummings OW, Ferrell LD, Liu YC, Torbenson MS, Unalp-Arida A, Yeh M, McCullough AJ, Sanyal AJ. Design and validation of a histological scoring system for nonalcoholic fatty liver disease. Hepatology. 2005;41:1313-21

20. Lee DC, Lau AS. Effects of Panax ginseng on tumor necrosis factor- $\alpha$-mediated inflammation: a mini-review. Molecules. 2011;16:2802-16.

21. Marchesini G, Brizi M, Bianchi G, Tomassetti S, Bugianesi E, Lenzi M, McCullough AJ, Natale S, Forlani G, Melchionda N. Nonalcoholic fatty liver disease: a feature of the metabolic syndrome. Diabetes. 2001;50:1844-50.

22. Mishra P, Younossi ZM. Current treatment strategies for non-alcoholic fatty liver disease (NAFLD). Curr Drug Discov Technol. 2007;4:133-40.

23. Michalany J. Histological technique in pathology: with instructions for the surgeon, nurse and cytotechnologist. 3 ed. São Paulo. 1998;295p.

24. Mollah ML, Kim GS, Moon HK, Chung SK, Cheon YP, Kim JK, Kim KS Antiobesity effects of wild ginseng (Panax ginseng C.A. Meyer) mediated by PPAR-gamma, GLUT4 and LPL in ob/ob mice. Phytother Res. 2009;23:220-5.

25. Nagasawa T, Inada Y, Nakano S, Tamura T, Takahashi T, Maruyama K, Shibata, N. Effects of bezafibrate, PPAR pan-agonist, and GW501516, PPARdelta agonist, on development of steatohepatitis in mice fed a methionine- and choline-deficient diet. Eur J Pharmacol. 2006;536:182-191.

26. Nakamoto K, Takayama F, Mankura M, Hidaka Y, Egashira T, Ogino T, Mori, A. Beneficial Effects of Fermented Green Tea Extract in a Rat Model of Non-alcoholic Steatohepatitis. J Clin Biochem Nutr. 2009;44:239-46.

27. Neuschwander-Tetri BA. Fatty liver and the metabolic syndrome. Curr Opin Gastroenterol. 2007;23:193-8.

28. Nobili V, Carter-kent C, Feldstein AE. The role of lifestyle changes in the management of chronic liver disease. BMC Med. 2011;6:9-70.

29. Sanyal AJ. American Gastroenterological Association. AGA technical review on nonalcoholic fatty liver disease. Gastroenterol. 2002;123:1705-25.

30. Sasaki Y, Shimada T, Iizuka S, Suzuki W, Makihara H, Teraoka R, Tsuneyama K, Hokao R, Aburada M. Effects of bezafibrate in nonalcoholic steatohepatitis model mice with monosodium glutamate-induced metabolic syndrome. Eur J Pharmacol. 2011;662:1-8.

31. Svegliati-Baroni G, Candelaresi C, Saccomanno S, Ferretti G, Bachetti T, Marzioni M, De Minicis S, Nobili L, Salzano R, Omenetti A,Pacetti D, Sigmund S, Benedetti A, Casini A. A model of insulin resistance and nonalcoholic steatohepatitis in rats: role of peroxisome proliferator-activated receptor-alpha and $n-3$ polyunsaturated fatty acid treatment on liver injury. Am J Pathol. 2006;169:846-60.

32. Wang H, Storlien LH, Huang XF. Effects of dietary fat types on body fatness, leptin, and ARC leptin receptor, NPY, and AgRP m RNA expression. Am J Physiol Endocrinol Metab. 2001;282:E1352-9.

33. Woods SC, Seeley RJ, Rushing PA, D'Alessio D, Tso PA. Controlled high-fat diet induces an obese syndrome in rats. J Nutr. 2003;133:1081-7.

Received 4/2/2014

Accepted 20/3/2014 